\title{
POLITICS DISCRETIONARY FUND BUDGET OF REGIONAL INCOME AND EXPENDITURE BEFORE AND ELECTION IN 2015 IN SAMARINDA CITY
}

\author{
Muhammad Habibi ${ }^{1}$, Suswanta ${ }^{2}$ \\ ${ }^{1}$ Master of Government Affairs and Administration Universitas Muhammadiyah Yogyakarta \\ ${ }^{2}$ lecturer Master of Government Affairs and Administration Universitas Muhammadiyah Yogyakarta \\ hㅡabibi.id@gmail.com; ${ }^{2}$ soes umy@yahoo.com \\ DOI: https://doi.org/10.18196/jgpp.61106
}

Article Info

Article history:

Received 15 Jan 2019

Revised 01 Feb 2019

Accepted 15 Feb 2019

\begin{abstract}
Expenditures on grants (Hibah) and sosial assistance (Bansos) which are included in the category of discretionary funds are very vulnerable to be used as campaign funds to gain popularity of incumbent couples. The purpose of this study is to investigate the possibility of an indication of abuse of discretionary funds in the APBD. This study used an interactive analysis model using three stages, namely; data condensation, presentation of concluding data, and verification. The results of this study indicated that the allocation of regional expenditures on grants and sosial assistance that carried out regional head election (Pemilukada) with the incumbent candidates is greater than before the election, which means there was the use of incumbent discretionary funds for their political interests. The allocation of regional discretionary funds that carried out the election with incumbent candidates was greater than the regions that do not implement the election. Increased of discretionary funds continue to occur despite the unhealthy / deficit regional financial condition. It coupled with the findings of the allocation of expenditure of goods distributed through 100 SKPD of Rp. $504,938,020,140,34$ to the public. This was a strong indication that the incumbent was trying to keep providing the assistance to attract voters on the Pemilukada in 2015.
\end{abstract}

Keyword -

Discretionary Fund, Incumbent, Grants, Sosial Assistance, Local Election.

\section{INTRODUCTION}

This regional development was carried out as an integral part of national development that was carried out through regional autonomy, so it provided opportunities for increasing democracy and regional performance. The implementation of autonomy was also useful in enhancing the welfare of the community towards an active and democratic civil society, for this reason, the community participation, openness and accountability to society are needed.

To support the implementation of regional autonomy through the provision of financing sources based on the principle of decentralization, it was necessary to regulate the financial balance between the central and regional governments in the form of a financial system. This financial system is used to finance the decentralization work program implemented in areas commonly referred as the Regional Budget (APBD). 
One of the decentralization activities is the direct implementation of the Regional Head General Election in each region. Based on data from the Indonesian Power of Democracy and Konrad Adenauer Stiftung in 2009, Indonesia has conducted Regional Head Elections (Pemilukada) directly since 2005 in each district / city. The activity of Pemilukada is the authority and responsibility of the regional government, regardless that the central government which only serves as a supervisory function.

During the election of regional heads, incumbent of regional heads tended to commit political bribery, to purchases the voters and taking various types of shopping and grants to cover a very large campaign expenditure (Dahlberg \& Johansson, 2002). However, during the second period where regional heads cannot be re-elected, regional heads will tend to commit corruption in order to seek a collateral when the position is stepped down (Ferraz \& Finan, 2011). The regional head who ends his leadership period and will go back to becoming a candidate for regional head will tend to use policy funds (discetionary funds) to increase his popularity in order to be reelected in the next period (Sjahrir, Kis-katos, \& Schulze, 2013).

Allegations of potential APBD irregularities will increase when the regional head re-nominates after his leadership period or incumbent, considering that they have to compete again, as not to lose the power. Incumbent will make changes in the composition of the budget to influence the voters (Drazen \& Eslava, 2006). This can be seen from the needs of regional heads when conducting campaigns to be re-elected in the next period, so that the regional head will take various kinds of shopping and grants from other parties and will make a vote purchase to be re-elected (Dahlberg \& Johansson, 2002). Grant Expenditures and Social Assistance Expenditures, is one of the expenditure posts that can be used by candidates for incumbent regional heads to lure the hearts of voters to get support. Incumbent will make changes to the composition of the budget to influence the voters (Drazen \& Eslava, 2006).

Forum Himpunan Kelompok Kerja (FH Pokja) 30, budget activists of Samarinda City believes that grants and social assistance are very vulnerable to be used as campaign funds to gain popularity of incumbent couples in the Samarinda Regional 
Election. Data compiled by Pokja 30 states that in 2013, the total grant's funds disbursed reached Rp 43 billion. This amount increased in 2014, where the grant was allocated Rp 136 billion. Also in 2015, not including the Revised APBD, the grant's funds have been allocated $\mathrm{Rp} 164$ billion, while Bansos for the same year is $\mathrm{Rp}$ $943,750,000$.

Based on that data, the author wants to see the reality that happened and conclude whether there is indeed a use of discretionary funds before and during the 2015 regional head general election in Samarinda City and is that an incumbent effort in the form of a political strategy to increase electability, maintain an incumbent voice base or something other. This study examined in the regulation, implementation and looks at aspects of grant and Bansos budgeting. Therefore, in this study, the author asks two questions. First, how was the allocation of discretionary funds before and during the Pemilukada? How was discretionary fund allocation compared to regional financial conditions? Then, how is the allocation of regional discretionary funds between the region that carry out Pemilukada with incumbent candidates, with the regions that do not implement Pemilukada?

Based on the description above, the researcher tries to link the legitimacy theory and agency theory. The emergence of legitimacy theory begins with an organization / company that seeks to establish harmony between social and environmental values with their business activities so that norms of business behavior can be accepted in a larger social system in which they are a part. This theory becomes important when applied to the public sector, especially social acceptance of government organizations led by regional heads who are legitimized by their people. Legitimacy according to Suchman, (1995) is defined as follows:

"Legitimacy is a generalized perception or assumption that the actions of an entity are desirable, proper, or appropriate within some socially constructed system of norms, values, beliefs, and definitions."

The application of legitimacy theory in the public sector can be seen when the regional head maintains legitimacy in order to be re-elected in the second period and not to lose from the otential competitors by trying as much as possible to draw 
sympathy from the people in various ways. One of choice is to provide grants and social assistance to improve its image in the community before the Pemilukada.

According to the relationship between Ritonga \& Alam's theory of agency and budgeting, (Ritonga \& Alam, 2010), it can be seen as a transaction in the form of a mandate contract given to agents (executives) within the framework of institutional structures with different levels. In accordance with what is stated in the agency theory, that principals and agents have their own interests, so that conflicts over these interests have the potential to occur at any time. The agent has the ability to further highlight his interests because he has more information than the principal, this is because the agent is in operational control in the field. So the agent prefers alternatives that benefit him, by deceiving and imposing losses on the principal Fozard, S., (2001) in Ritonga \& Alam, (2010)

This research was a qualitative descriptive study. This research was conducted in the City of Samarinda. This location was chosen because the author portrays the increasing discretionary fund phenomenon in the lead up to the 2015 post-conflict local election. This study used interactive model data analysis

\section{A. Research Focus}

The focus or indicators measured in this study are:

1. Allocation of discretionary funds before and during the Pemilukada.

2. Allocation of discretionary fund compared to regional financial conditions.

3. Differencies between allocation of regional discretionary funds that carry out Pemilukada with incumbent candidates with the regions that do not implement Pemilukada.

\section{B. Data Collection Techniques}

Data collection techniques in this study used triangulation methods which are done by comparing information or data in different ways. To obtain the truth of reliable information and a complete picture of certain information, researchers used interviews and observations to check the truth. In addition, researchers also used different informants to check the truth of the information. Through various perspectives it is hoped that results can be obtained close to the truth. Therefore, this 
stage of triangulation is carried out if the data or information obtained from the subject or research informant is in doubt.

\section{Analysis Tools}

This study used an interactive model data analysis introduced by Miles, Huberman, \& Saldaña, (2014), where there were three activities that occur simultaneously; data condensation, presentation of concluding data, and verification.

\section{RESULT AND DISCUSSION}

Spending on social assistance grants and expenditures is a shopping outpost that can be used for incumbent candidates to lure the voters to get votes. This reason is a basic because in Permendagri 59 of 2007 which was a revision of Permendagri 13 of 2006, these two types of expenditure are part of the indirect expenditure component which distribution does not go through programs and activities and does not have certain performance targets, so the allocation tends to be subjective (political interest) and the realization of the expenditure is based on the initiative of the Mayor in the form of Regional Head Regulations.

According to Halim \& Kusufi, (2012), opportunistic of incumbent candidates in the process of drafting the APBD ahead of the implementation of the Regional Head General Election were very strong. As an incumbent candidate, the regional head that will compete in Pemilukada has a great opportunity to utilize spending posts on the APBD for their interests. The APBD drafting process begins with proposals submitted by executives (Regional Governments) which are indicated to be of the highest importance to executive interests. With the superiority of power it has, the incumbent will tend to propose a budget that can enlarge its agency, both financially and non-financially.

Minister of Home Affairs, Tjahjo Kumolo, even stated that Bansos funds had increased by 1000 percent before the implementation of regional elections. He added that there were 89 regions that increased to 1000 percent in the Indonesian Forum data for Budget Transparency (FITRA), ICW, and the Ministry of Home Affairs' Finance Director. The second level APBD for the Regency and City is jointly approved by the Governor, Regent, Mayor, and DPRD so that data negotiation is very 
34. vulnerable. Data obtained by the election monitoring agency shows an increase in the number of social assistance funds and grants in the APBD whose regional heads advanced in the 2015 General Election, so that the increase was considered to be potentially misused to carry out money politics.

\section{A. Discretionary Fund Allocation Before and During the Regional Election}

The trend of increasing discretionary funds that also occurred in the city of Samarinda reflected in the financial statements of local governments in the 2013-2015 budget year, where the upward trend only occurred before the election process that would take place. The Pokja 30 Director, Carolus Tuah, said that the recipients of social assistance funds and grants certainly had political affiliation as incumbent supporters. The lack of role in encouraging public openness by the bearer party in the 2015 General Election, which was called Carolus Tuah, made everything closed, including the recipient of this government assistance fund.

This study tried to look at the proportion of discretionary fund allocations before and during the Pemilukada, based on the Samarinda City Regional Government Financial Report (LKPD) 2013-2015 which was audited by the BPK. The proportion of regional grant expenditures with incumbent candidates experienced an increase before the Pemilukada, but after the Pemilukada the grant expenditure experienced a drastic decline from before the Pemilukada became a strong indication that the incumbent carried out political discretionary funds before the Pemilukada in order to increase its popularity with the aim of being elected again in the 2015 General Election. It can be seen in the graph below:

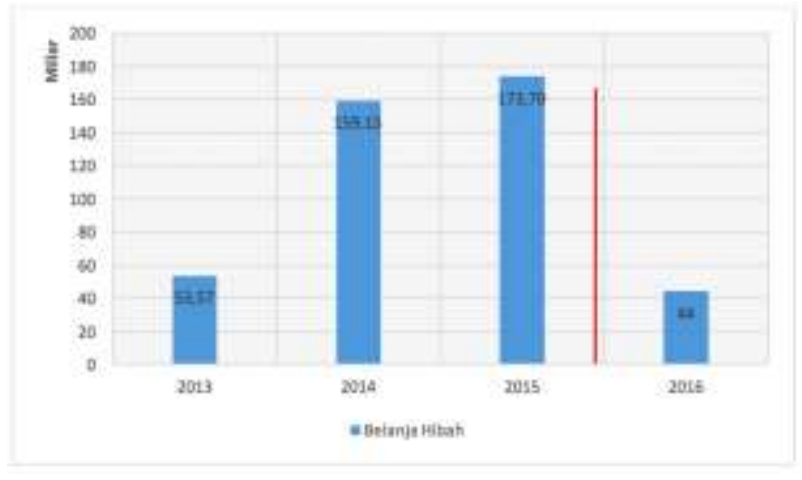

Figure 1. Samarinda City Grants Shopping Trends 2013-2016 
Government policy in providing Bansos is given selectively, not continuously or nonbinding (giving is not mandatory and does not have to be given every year), except in certain circumstances and has the clarity of the allocation of its use by considering regional financial capabilities. Social assistance spending is provided in accordance with the provisions of Permendagri No. 39 of 2012 concerning Guidelines for Granting Grants and Bansos sourced from Regional Revenues and Expenditures. After the post-conflict local election period, there was a significant decrease of $74.6 \%$, but there was an increase in social assistance spending accounts of $47 \%$. For more details, the allocation of the Bansos of Samarinda City can be seen in the graph below:

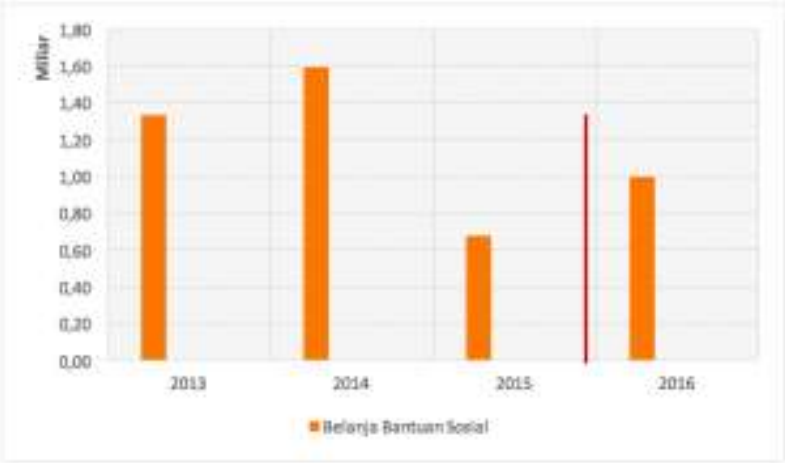

Figure 2. Trend of Samarinda City Social Assistance Expenditure for 2013-2016

In the 2015 budget year, the Samarinda City Government budgeted goods and services worth Rp. 959,428,741,498.46 and realized worth Rp. 813,270,571,725.38. The realization included Rp. 504,938,020,140,34 is used for the expenditure of goods delivered to the community, namely farmer groups, breeders groups, and business groups managed by 100 Technical SKPD.

If it is correlated with the City of Samarinda Regional Medium Term Development Plan (RPJMD) 2011-2015, the main focus of the development of the potential of Samarinda City in the trade, hotels, and restaurants sector, not on the agricultural and plantation sectors. Based on the Samarinda City RPJMD 2011-2015 the agriculture and fisheries sector is not is a sector that can be relied upon as the backbone of the economy, but is utilized in supporting grill resistance. The agricultural sector includes food crops, plantations, forestry, livestock, and fisheries. The contribution of the agricultural sector (agriculture) tends to be fixed and very small, from $2.38 \%$ in 2000 to $2.20 \%$ in 2008 . Based on this, the development of the 
agricultural sector in Samarinda is not the main sector as the backbone of the economy. The development of the agricultural sector is directed at meeting the basic needs themselves as well as supporting industrial activities.

However, the goods shopping account managed by 100 Technical SKPD is handed over to the community, namely farmer groups and business groups, which is a separate problem in the RPJMD of agriculture and plantations, not a priority program, but the budget allocation that given is very large. This is also an indication of the incumbent's use of discretionary funds as an agent who has legitimacy in the government for the sake of his popularity in the 2015 Pemilukada.

The granting of grants and Bansos must hold on to the principles of justice, propriety, rationality, and broad benefits for the community so that they are far from personal and group interests, and political interests of the elements of local government. Therefore, the government issued Permendagri Number 32 of 2011 concerning Guidelines for Granting Grants and Social Assistance sourced from the APBD, which was changed to Permendagri No. 39 of 2012 with the process of disbursing grants and Bansos that were more stringent than the previous process.

The stages and mechanism of the budget formulation process between grant and social assistance spending from 2009 to 2013 have no fundamental differences. After the issuance of Pemendagri No. 39 of 2012, grant and social assistance budgeting no longer uses the package system, but rather includes the recipient's name, recipient's address, and the amount of the grant and social assistance in Annex III of the Regional Head Regulation on the APBD Description.

The strict regulation does not guarantee that the budget for grants and social assistance is not misused for personal gain, especially in the lead up to the 2015 General Election. Based on Permendagri No. 21 of 2011, which is the second change from Permendagri No. 13 of 2006, this grant and social assistance expenditure is included in the expenditure category indirectly whose allocation is not based on certain performance targets so that the determination of the amount of the budget tends to be subjective and susceptible to the corruption. 
Another problem arised from the granting of grants that ensnare the chairman of the KNPI Samarinda DPD Harman Al Idrus, Harman officially becomes a suspect on May 20, 2016. He allegedly misused the KNPI Samarinda grant for the 2013-2014 period. In addition, there are allegations of inflation of activity funds. To note, in 2013, KNPI Samarinda received a grant from Samarinda's pure APBD of Rp. 3 billion, plus Rp. 1.5 billion from the revised APBD. Then in 2014, again received a grant of Rp. 3 billion from the pure APBD and an additional Rp. 2 billion through the APBD changes.

Based on the results of the analysis it is known that the proportion of Grant Expenditures and for incumbent candidates at the time of the Pemilukada was greater than before the implementation of the Pemilukada. Thus the results of this study also reinforced the results of research conducted by 6 [6]. It is known that the allocation of grant expenditure for regions with incumbent candidates at the time of the Pemilukada was greater than before the implementation of the Pemilukada, and research conducted by Indonesia Corruption Watch (ICW) in 2008 in collaboration with Murdoch University, found an increase in the allocation of expenditure on grants and social assistance spending in the APBD during the 2008 General Election in Tabanan (Bali), Bau-Bau City (Southeast Sulawesi), and Bandung City (West Java) followed by candidate wins incumbent. Executives who were agents receive authority and exercise authority and also have discretionary power that can be utilized to maintain their position in the government by using discretionary funds that can be freely channeled due to indirect types of spending. With an indication of the incumbent's APBD utilization for its candidacy again, the government needs to make a tighter control on spending on aid and social assistance expenditures starting from the procedures for budgeting, implementation, reporting and control. However, the use of public funds is disguised as a populist policy / program so that it has a legal basis and the consequences are not easily accused of abuse of power or election violations.

\section{B. Discretionary fund allocation compared to regional financial conditions}

Permendagri Number 32 of 2011 jo. Permendagri No. 39 of 2012 Article 4 and Article 22 states that the allocation of the budget for grants and social assistance 
must take into account the regional financial capacity after prioritizing the fulfillment of obligatory affairs expenditure by taking into account the principles of justice, propriety, rationality, and benefits for the community. Regional financial capability in terms of budget perspective as a managerial control tool states that the government has enough money to fulfill its obligations 9 [9].

Thus, the financial capacity of this region can be measured by fiscal space. Fiscal space is a concept to measure the flexibility that local governments have in allocating APBD to finance activities that are regional priorities. The greater the fiscal space that an area has, the greater the flexibility that local governments have to allocate their expenditure. Based on research 10 [10], fiscal space has a positive influence on the performance of local government, but on the contrary it can be used as an opportunity to commit corruption. The allocation of expenditure on grants and social assistance with the personal motives of the head of the region is also an indication of undercover corruption.

The amount of budget allocation for grant and social assistance expenditure was inseparable from the characteristics of each region. Research 11 [11] states that of several characteristics of local government, namely the independence ratio, human development index, legislative size, and status; only status that affects the allocation of social assistance spending.

In 2013-2015 the financial condition of Samarinda City continued to experience a budget deficit, but continued to allocate discretionary funds which basically disrupted the budget performance that had been prepared without paying attention to mandatory and non-compliance. So this reinforces the alleged use of the incumbent's discretionary fund for his candidacy again. More can be seen in the graph below: 


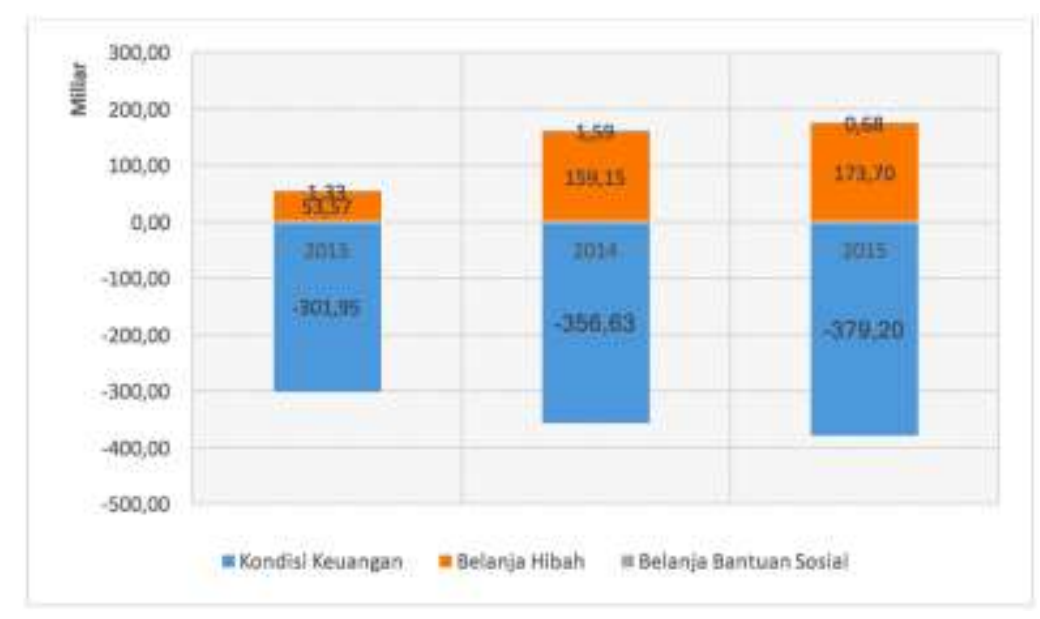

Figure 3. Discretionary Fund Allocation Compared to Regional Financial Conditions in 2013-2015

\section{Allocation of Regional Discretionary Funds that Execute Election with}

\section{Incumbent Candidates with Regions that Do Not Implement Election}

Based on the results of the analysis, it is known that the proportion of discretionary fund allocation in implementing regions of the Pemilukada with incumbent candidates is greater than the proportion of grant expenditure and social assistance spending in regions that do not implement Pemilukada. With the indication of the incumbent's APBD utilization for its candidacy again, the government needs to make a tighter financial control for Grant Expenditures and Social Assistance Expenditures. But the government must balance between fiscal decentralization and regulatory rigor. That is, there are complete and firm rules, but they do not reduce the authority of the regions to manage their regional finances according to the needs and aspirations of their people. However, the use of public funds is disguised as a populist policy / program so that it has a legal basis and the consequences are not easily accused of abuse of power or election violations. The results regarding the comparison of Samarinda City grant expenditure and Penajam Paser Utara District can be seen in the graph below: 


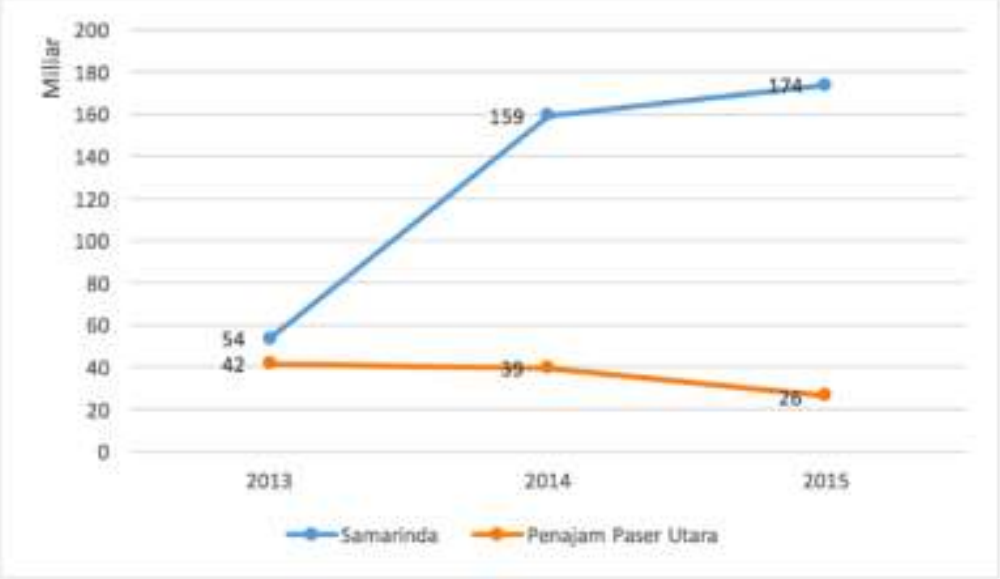

Figure 4. Comparison of Samarinda City Grants and Penajam Paser Utara District Expenditures 2013-2015 Whereas social assistance spending has decreased, for more details can be seen in the notes below :

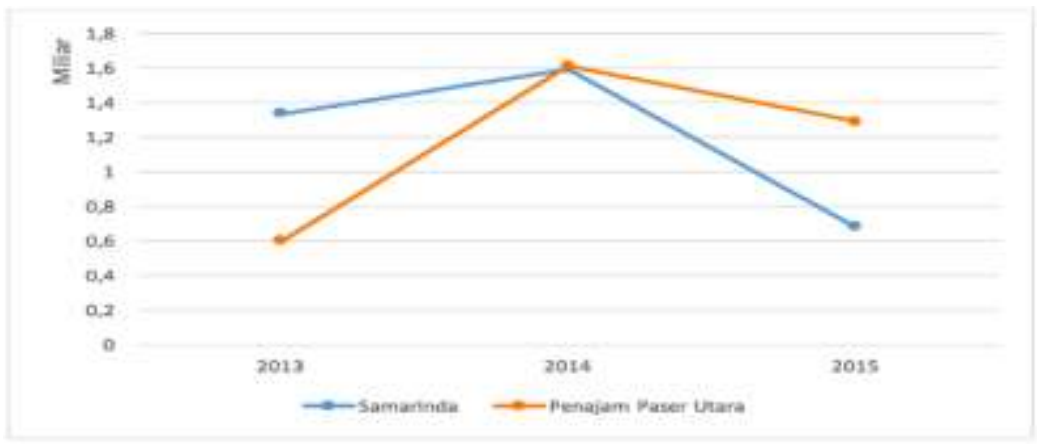

Figure 5. Comparison of Samarinda City Social Assistance Expenditures and Penajam Paser Utara

District 2013-2015

With an indication of the incumbent's APBD utilization for its candidacy again, there should be stricter supervision by both DPRD members and the Government Internal Supervisory Apparatus (APIP) on the allocation and realization of grant and social assistance expenditures especially towards the political year to be right on target. Researchers also suggest restrictions on the allocation of expenditure on grants and social assistance based on the ability of regional finances (fiscal space) as outlined in government regulation policies as improvements to existing rules so that the allocation of grant and social assistance budgets is controlled through a system of rules. 


\section{CONCLUSION}

Based on the discussion that has been done, the conclusion of this study are:

1. Allocation of regional discretionary funds with incumbent candidates before and during Pemilukada experienced a drastic increase in the lead up to Pemilukada and social assistance spending decreased by a tendency to fluctuate but there were findings of the allocation of goods expenditure in 2015 distributed through 100 Technical SKPD of Rp. 504,938,020,140.34 to the public at a time when regional financial conditions are in deficit.

2. There is an increase in expenditure on grant and social assistance spending, still occurring despite the financial condition of the 2013-2015 budget deficit. This is an indication that the incumbent is trying to keep providing assistance to attract voters' interest on Pemilukada in 2015.

3. Furthermore, the proportion of the allocation of discretionary funds in the implementing regions of Pemilukada with incumbent candidates is greater than the proportion of discretionary funds in regions that do not implement Pemilukada. Based on the conclusions drawn from the research findings, it is suspected that there is a political discretionary fund by the incumbent for its political interests.

\section{REFERENCES}

Dahlberg, M., \& Johansson, E. (2002). On the Vote-Purchasing Behavior of Incumbent Governments Published by: American Political Science Association On the Vote-Purchasing Behavior of Incumbent Governments Are grants from central to lower-level govern-, 96(1), 27-40.

Drazen, A., \& Eslava, M. (2006). Electoral Manipulation via Voter-Friendly Spending : Theory and Evidence, (July).

Ferraz, C., \& Finan, F. (2011). American Economic Association Electoral Accountability and Corruption : Evidence from the Audits of Local Governments Author ( $\mathrm{s}$ ): Claudio Ferraz and Frederico Finan Source: The American Economic Review, Vol . 101, No . 4 ( JUNE 2011 ), pp . 1274-1311. The American Economic Review, 101(4), 1274-1311.

Halim, A., \& Kusufi, S. (2012). Akuntansi Sektor Publik: Teori, Konsep dan Aplikasi. Jakarta: Salemba Empat.

Miles, M. B., Huberman, A. M., \& Saldaña, J. (2014). Qualitative Data Analysis A Methods Sourcebook. USA: Arizona State University. 
Ritonga, T., \& Alam, M. I. (2010). Apakah Incumbent memanfaatkan Anggaran Pendapatan dan Belanja Daerah (APBD) untuk mencalonkan kembali dalam Pemilihan Umum Kepala Daerah (Pemilukada). Jurnal Simposium Nasional Akuntansi (SNA) X, (4), 1-25.

Sjahrir, B. S., Kis-katos, K., \& Schulze, G. G. (2013). Political Budget Cycles in Indonesia at the District Level. Economics Letters, 120(2), 342-345. https://doi.org/10.1016/j.econlet.2013.05.007

Suchman, M. C. (1995). Managing Legitimacy: Strategic and Institutional Approaches Author ( s): Mark C. Suchman Source: The Academy of Management Review , Vol . 20 , No . 3 ( Jul ., 1995 ), pp . 571-610 Published by: Academy of Management Stable URL: http://www.jstor.org/. The Academy of Management Review, 20(3), 571-610. https://doi.org/10.2307/258788 